\title{
Charismatic leadership among nursing professionals: an integrative review
}

\author{
Liderança carismática entre os profissionais de enfermagem: revisão integrativa \\ Liderazgo carismático entre profesionales de enfermería: revisión integrativa
}

\begin{abstract}
André Almeida de Moura'
ORCID: 0000-0003-2990-5375
\end{abstract}

Karen Yukari Hayashida'

ORCID: 0000-0001-7429-9410

Andrea Bernardes'

ORCID: 0000-0002-9861-2050

Ariane Cristina Barboza Zanetti'

ORCID: 0000-0002-4458-3274

Carmen Silvia Gabriel'

ORCID: 0000-0003-2666-2849

'Universidade de São Paulo, Ribeirão Preto College of Nursing. Ribeirão Preto, São Paulo, Brazil.

How to cite this article:

Moura AA, Hayashida KY, Bernardes A,

Zanetti ACB, Gabriel CS. Charismatic leadership among nursing professionals: an integrative review. Rev Bras Enferm [Internet]. 2019;72(Suppl 1):315-20. [Thematic Issue: Work and Management in Nursing]. DOI: http://dx.doi.org/ 10.1590/0034-7167-2017-0743

Corresponding Author:

André Almeida de Moura

E-mail: andalmo@usp.br

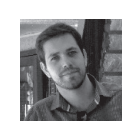

Submission: 10-18-2017

Approval: 05-25-2018

\section{ABSTRACT}

Objective: Analyze the literature for knowledge about charismatic leadership among nursing professionals. Method: This is an integrative review of the literature that searched for studies published in English, Portuguese and Spanish until 2016 in the following electronic databases: LILACS, Pubmed, SCOPUS, Web of Science, and CINAHL. Results: Three studies were selected from a total of twenty-one studies; they were arranged in two categories: validation of a charismatic leadership instrument and effects of charismatic leadership on followers' initiative-oriented behavior. Conclusion: Charismatic leadership is considered an important skill for nursing professionals as they generate a positive influence on followers, especially in times of crisis and changes. Considering the relevance of this style of leadership, the need to develop further studies on this subject is reinforced, given the low number of studies found in the literature. Descriptors: Leadership; Nursing; Health Services Administration; Personnel Management; Professional Competence.

\section{RESUMO}

Objetivo: Analisar o conhecimento produzido acerca da liderança carismática entre os profissionais de enfermagem. Método: Trata-se de uma revisão integrativa da literatura por meio de buscas nas seguintes bases de dados eletrônicas: LILACS, Pubmed, SCOPUS, Web of Science e CINAHL, sendo artigos publicados em inglês, português e espanhol, até o ano de 2016. Resultados: De um total de vinte e um artigos encontrados, foram selecionados três e divididos em duas categoriais: estudo de validação de instrumento de liderança carismática e efeitos da liderança carismática no comportamento da iniciativa orientada dos seguidores. Conclusão: Ressalta-se que a liderança carismática é apontada como competência importante para profissionais da enfermagem e gera influências positivas nos seguidores, sobretudo em momentos de crise e de mudanças. Diante da relevância desse estilo de liderança, reforça-se a necessidade do desenvolvimento de mais estudos sobre a temática, tendo em vista a pequena quantidade de artigos encontrados.

Descritores: Liderança; Enfermagem; Administração de Serviços de Saúde; Administração de Recursos Humanos; Competência Profissional.

\section{RESUMEN}

Objetivo: Analizar el conocimiento producido sobre liderazgo carismático entre profesionales de enfermería. Método: Revisión integrativa de la literatura, habiéndose realizado búsquedas en las bases de datos electrónicas: LILACS, Pubmed, SCOPUS, Web of Science y CINAHL, consistente en artículos publicados en inglés, portugués y español, hasta el año 2016. Resultados: De un total de veintiún artículos encontrados, fueron seleccionados tres, y divididos en dos categorías: estudio de validación de instrumento de liderazgo carismático y efectos del liderazgo carismático en la conducta de la iniciativa-orientada de los seguidores. Conclusión: Cabe resaltar que el liderazgo carismático es considerado una competencia importante en profesionales de enfermería, y que genera influencia positiva a los seguidores, particularmente en momentos de crisis y de cambios. Ante la relevancia de este tipo de liderazgo, toma fuerza la necesidad de desarrollar más estudios sobre la temática, considerando la escasa cantidad de artículos encontrados.

Descriptores: Liderazgo; Enfermería; Administración de los Servicios de Salud; Administración de Personal; Competencia Profesional. 


\section{INTRODUCTION}

Over the last few years, many changes have taken place in socioeconomic, political, ethical and philosophical contexts. Labor relations have also undergone transformations and changes in paradigms. Then knowledge incorporated a broader and more flexible view, requiring courses and training to incorporate new skills, such as leadership ${ }^{(1-2)}$.

In this sense, the labor market has increasingly demanded leadership practice from nursing professionals ${ }^{(3)}$. Such leadership in health organizations is in a process of transition from more rigid and hierarchical models to leadership models based on flexibility and democracy, enabling environments of collective discussion ${ }^{(4)}$. These changes have required the entrepreneurship of professionals and relational characteristics to manage care and exercise their leadership, in order to qualify care and drive institutional improvements $s^{(5)}$.

When observing the national curricular guidelines of the nursing undergraduate course of 2001, leadership is an appreciated skill included in the general competences of nurse training. These guidelines reinforce the importance of nurse leadership linked with multidisciplinary teamwork and nursing professionals that are ready to assume leadership roles, always considering community well-being ${ }^{(6)}$. Leadership involves commitment, accountability, empathy, decision making, communication, and management in an effective and efficient way. Consistent with this perspective, students with leadership training present more chances of success and professional promotion ${ }^{(7)}$. In addition, nursing schools must, therefore, invest in training of professionals prepared to deal with teams that play leadership roles in an efficient way, ensuring the quality of care provided to patients ${ }^{(8)}$.

Leadership in nursing refers to the ability to influence the team, so that together they can achieve shared goals, observing the central idea of fulfilling the health needs of patients and their families ${ }^{(9)}$. Good leaders can build trustful relationships because they know the skills and motivations of their team members and promote healthier work environments that favor patient safety and improve quality of care ${ }^{(10-11)}$. In addition, leaders must adapt to different situations, identify the best strategies to be implemented in their group and analyze their followers and the context in which they are inserted, creating the means to perform their work ${ }^{(12)}$.

Still regarding the profile of a leader in nursing, it is early to outline personal characteristics of leaders and leadership styles in their different fields of action. Few studies have been conducted on this topic with results that contribute to the knowledge of this field, as seen in an integrative review on leadership in nursing ${ }^{(13)}$.

In addition, a study about leadership in nursing showed that nurses have used leadership theories for reference in their research, but still in a small number of studies. In an investigation that analyzed 57 studies, only $12(21.05 \%)$ used theories for reference. This confirms the fragile theoretical base of nurses regarding leadership, which is directly related to poor instrumentalization of these professionals to use such practice in their workplace and non-appreciation of this skill in nurse training ${ }^{(1)}$.

Given the flexibility of leadership, leaders can adopt different leadership styles and theories if necessary, as nurses are faced with diverse situations every day, and no particular leadership style can suit all situations. Therefore, nurses should be flexible in their leadership styles and adapt them to different circumstances ${ }^{(14)}$.

Among the different styles of leadership, charismatic leadership, proposed by researcher Robert House, has a focus on the leader's effects on values, emotions, motivations, and self-esteem. The author formulated a number of hypotheses about the characteristics and behaviors of charismatic leaders, as they adapted to different situations and to the effectiveness achieved in their roles ${ }^{(15)}$.

Charismatic leaders have the following characteristics: high self-confidence, mastery, and conviction in the moral integrity of their beliefs ${ }^{(15)}$. Another strong point of charismatic leaders is communication, according to a Dutch study. Among the leadership styles, charismatic leadership presented the strongest correlation with effective communication ${ }^{(16)}$; in addition, charismatic leaders are active participants, that is, they actively collaborate to improvements in the workplace, even exerting influence to such purposes ${ }^{(17)}$.

A study about self-concept, implicit leadership theory, and leadership preferences by followers reported that charismatic leaders have high expectations in terms of performance, trust their followers' abilities to achieve goals, take risks by opposing status quo, and emphasize a view of collective identity ${ }^{(18)}$.

\section{OBJECTIVE}

Identify, in national and international literature, studies about charismatic leadership in nursing practice.

\section{METHOD}

\section{Ethical aspects}

Ethical aspects and copyrights with reference to the authors of the studies analyzed were respected while conducting this review. Due to the bibliographic nature of this study, project approval by a research ethics committee was not required.

\section{Study design and period}

This study refers to an integrative review of the literature, which is a method that allows the synthesis of multiple published studies and general conclusions about a specific focus of study. In addition, this type of review uses the methodology, theory or evidence of distinct studies whose designs are varied ${ }^{\left({ }^{(19)}\right.}$. Data were collected, recorded and analyzed from March to August 2017.

\section{Population or sample; inclusion and exclusion criteria}

Studies were selected from electronic databases: Latin American and Caribbean Center on Health Sciences Information (LILACS), National Library of Medicine (PubMed), SCOPUS (SciVerse Scopus), Web of Science, and Cumulative Index to Nursing and Allied Health Literature (CINAHL). The descriptors used were: controlled DeCS (leadership; nursing) and MeSH descriptors (leadership, nursing) and non-controlled descriptors (charismatic leadership). Boolean logical operator AND was adopted to match the terms, aiming to obtain as many studies as possible to answer the guiding question. 
This review included studies published until 2016 in English, Portuguese and Spanish, without an initial year of search to allow as many studies as possible on the subject. Theses, dissertations, opinion articles, and editorials were excluded.

\section{Study protocol}

This study was conducted in six steps: 1) formulation of the guiding question; 2 ) definition of inclusion and exclusion criteria, and search in the literature; 3 ) definition of the information to be extracted and categorized;4) evaluation of the selected studies; 5) interpretation of results; and 6) synthesis of knowledge produced ${ }^{(20-21)}$.

The studies selected for this review were categorized according to their levels of evidence: level I (evidence from a systematic review, meta-analysis or guidelines of all randomized controlled trials - RCT); level II (evidence obtained through one or more welldesigned RCTs); level III (evidence from non-randomized controlled studies); level IV (evidence from well-designed case-control studies or cohort studies); level V (evidence from systematic reviews of qualitative and descriptive studies); level VI (evidence resulting from a single descriptive or qualitative study); and level VII (evidence from opinions of experts and/or reports of expert committees ${ }^{(22)}$.

The guiding question of this review was: What is the knowledge identified in the national and international literature about charismatic leadership among nursing professionals?

\section{Analysis of results and statistics}

Data were evaluated using descriptive analysis, based on the protocol above, which allows readers to evaluate the applicability of the integrative review. In addition, based on the literature on the subject, the results were discussed to identify positive contributions to nursing practices, especially to the management and administration of nursing services.

\section{RESULTS}

The initial search obtained 21 studies. After reading their abstracts and evaluating the inclusion and exclusion criteria, 12 articles were discarded because they did not meet the criteria and six articles were repeated in the databases. Thus, three articles were selected, which answered the guiding question of this study. Chart 1 shows the search in the literature and Chart 2 shows the synthesis of the selected articles.

All three selected studies were descriptive studies, level of evidence $\mathrm{VI}$, conducted from 2008 to 2013. Two of them were focused on nurses, but their sample included professionals from other fields (physicians and medical technicians). The third study, conducted in Brazil, addressed the nursing team only. Research about this subject, although attracting the interest of nursing researchers in other countries, is still incipient worldwide.

For the purposes of analysis and discussion of the studies identified, two categories were created: Validation study for charismatic leadership instrument; Effects of charismatic leadership on followers' initiative-oriented behavior.

Chart 1 - Database search results, Ribeirão Preto, São Paulo, Brazil, 2016

\begin{tabular}{|c|c|c|c|c|}
\hline Database & Descriptors & $\begin{array}{l}\text { Studies } \\
\text { found }\end{array}$ & $\begin{array}{c}\text { Studies excluded } \\
\text { (repeated and/or not } \\
\text { meeting the inclusion } \\
\text { criteria) }\end{array}$ & $\begin{array}{l}\text { Studies } \\
\text { selected }\end{array}$ \\
\hline LILACS & $\begin{array}{l}\text { Leadership AND } \\
\text { nursing AND } \\
\text { charismatic } \\
\text { leadership }\end{array}$ & 1 & 0 & 1 \\
\hline Pubmed & $\begin{array}{l}\text { Leadership AND } \\
\text { nursing AND } \\
\text { charismatic } \\
\text { leadership }\end{array}$ & 3 & 3 & 0 \\
\hline Scopus & $\begin{array}{l}\text { Leadership AND } \\
\text { nursing AND } \\
\text { charismatic } \\
\text { leadership }\end{array}$ & 4 & 3 & 1 \\
\hline $\begin{array}{l}\text { Web of } \\
\text { Science }\end{array}$ & $\begin{array}{l}\text { Leadership AND } \\
\text { nursing AND } \\
\text { charismatic } \\
\text { leadership }\end{array}$ & 11 & 10 & 1 \\
\hline CINAHL & $\begin{array}{l}\text { Leadership AND } \\
\text { nursing AND } \\
\text { charismatic } \\
\text { leadership }\end{array}$ & 2 & 2 & 0 \\
\hline Total & & 21 & 18 & 3 \\
\hline
\end{tabular}

Chart 2 - Characterization of studies by journal, year, country, professionals involved and study type/level of evidence, Ribeirão Preto, São Paulo, Brazil, 2016

\begin{tabular}{|c|c|c|c|c|c|}
\hline Journal & Year & Country & $\begin{array}{l}\text { Nursing professionals involved/ } \\
\text { (number of participants) }\end{array}$ & $\begin{array}{l}\text { Study type/ } \\
\text { Level of } \\
\text { evidence }\end{array}$ & Outcome \\
\hline $\begin{array}{l}\text { Acta Paulista de } \\
\text { Enfermagem }\end{array}$ & 2013 & Brazil & Nursing team/(211) & $\begin{array}{l}\text { Descriptive } \\
\text { VI }\end{array}$ & $\begin{array}{l}\text { A translated version of the Charismatic } \\
\text { Leadership Socialized Scale was } \\
\text { validated and adapted to the hospital } \\
\text { context }^{(15)} \text {. }\end{array}$ \\
\hline HealthMED & 2012 & Turkey & Nurses/(297) & $\begin{array}{l}\text { Descriptive } \\
\text { VI }\end{array}$ & $\begin{array}{l}\text { A significant relationship was observed } \\
\text { between charismatic leadership and } \\
\text { followers' initiative-oriented behavior }^{(23)} \text {. }\end{array}$ \\
\hline $\begin{array}{l}\text { Health Care } \\
\text { Management } \\
\text { Review }\end{array}$ & 2008 & Germany & $\begin{array}{l}\text { Nurses/ (543 professionals, including } \\
\text { a physician in the sample) }\end{array}$ & $\begin{array}{l}\text { Descriptive } \\
\text { VI }\end{array}$ & $\begin{array}{l}\text { A significant and positive relationship } \\
\text { was found between charismatic } \\
\text { leadership and initiative-oriented } \\
\text { behavior }^{(24)} \text {. }\end{array}$ \\
\hline
\end{tabular}




\section{DISCUSSION}

\section{Validation study for charismatic leadership instrument}

The studies about charismatic leadership included a study for the adaptation of the Charismatic Leadership Socialized Scale to the Brazilian culture and analysis of psychometric properties of the translated and adapted version. This scale comprises 143 items that measure Charismatic Leadership, Instrumental Leadership, Commitment and Satisfaction, Motivation, and Team Effectiveness. In this scale, the first 124 items evaluate the behaviors of the manager and the other 19 items correlate the team actions according to the dimensions Commitment, Satisfaction, Motivation and Effectiveness ${ }^{(15)}$.

The instrument was translated into Portuguese by two Brazilian translators, adapted and applied to the target audience; the main psychometric characteristics were defined after the author's authorization. A total of 211 nursing professionals participated in this evaluation; they were from a public hospital, subordinate to the nurse manager of the unit and/or shift. The participants highlighted selfconfidence, determination, role modeling and integrity as the most relevant characteristics of nurse manager leadership. In Instrumental Leadership, Team Guidance and Role Clarification were the subscales that presented the highest scores. Statistical analyses (Varimax and Cronbach index) to verify instrument reliability showed good internal consistency of the items, with values near those obtained by the author of the original scale, thus justifying the usefulness of this scale adapted to the hospital context ${ }^{(15)}$.

A validation study indicates that this process is an important tool for nurse researchers, since instruments developed and/or adapted to Brazilian Portuguese are scarce, thus increasing the possibilities of research in this field of knowledge, contributing to broaden scientific evidence ${ }^{(25)}$.

Validation studies are widely used in research in several fields of knowledge. An integrative review about validation studies in nursing, conducted from January 1, 2004 to April 30, 2009, found that, of the 21 studies analyzed, two were published in 2005, six in 2006, four in 2007 and nine in 2008. This shows an increase in the number of validation studies in the last years, demonstrating a greater interest of nurses in the subject ${ }^{(25)}$.

\section{Effects of charismatic leadership on followers' initiative- oriented behavior}

The two studies included in this review that were not conducted in Brazil ${ }^{(23-24)}$ analyzed the impact of charismatic leadership on followers' initiative-oriented behavior. The same instrument ${ }^{(26)}$ was used in both studies.

These studies defined the initiative-oriented behavior, such as employees' commitment in having a future-oriented initiative that supports ongoing change processes in the workplace and improved results. According to the researchers, followers'initiativeoriented behavior (or simply initiative) can hardly be defined through formal regulations; on the contrary, it is discretionary. The definition of the construct on initiative-oriented behavior is related to similar constructs, such as proactive behavior, the dimension of civic virtue of organizational citizenship behaviors, and individual task proactivity ${ }^{(23)}$.
Charismatic leadership is defined in these studies as the relationship between an individual (leader) and one or more followers, based on leader behaviors combined with favorable attributions of followers. Charismatic leaders are often described as facilitators for change and communication in vision and high-performance expectations. This style of leadership has been useful especially in times of crisis and change ${ }^{(24)}$.

A study published in Germany had a sample of 543 professionals (including physicians and nurses) from six German private and public hospitals. This study guided the development of another study described below, conducted in Turkish hospitals. Three hypotheses were tested; first: charismatic leadership is positively related to followers' initiative-oriented behavior; second: followers' autonomy in the workplace will moderate the relationship between charismatic leadership and followers' initiative-oriented behavior, making this relationship stronger under high levels of autonomy in the workplace; and third: tension/stress of followers will moderate the relationship between charismatic leadership and followers' initiative-oriented behavior, making this relationship stronger under low levels of tension ${ }^{(24)}$.

A positive effect of charismatic leadership on initiative-oriented behavior was observed, as the authors of the study suspected. Also, the interaction between charismatic leadership and autonomy in the workplace was a significant predictor of initiative-oriented behavior, that is, the analyses showed that professional autonomy of the followers is positively related to their initiative-oriented behavior. Regarding the tension/stress interaction of followers and charismatic leadership, no significant data were evidenced, thus, the third hypothesis was not confirmed through data of this study ${ }^{(24)}$.

The study developed in public hospitals in Turkey had a sample of 402 professionals, including 297 nurses. It was conducted in a period of changes in the health system in Turkey aiming to promote governance, efficiency, satisfaction among patients and suppliers, and long-term sustainability of resources. The study tested hypotheses about the relationship between charismatic leadership, stress, autonomy in the workplace, and initiativeoriented behavior, like the study conducted in Germany. The authors observed a significant and positive relationship between charismatic leadership and initiative-oriented behavior, but also a significant and negative relationship between stress and initiative-oriented behavior. In addition, there was no statistical significance between charismatic leadership and autonomy in the workplace. The authors concluded that charismatic leadership is the strongest predictor of initiative-oriented behavior in followers followed by stress/tension(23).

In both studies, the authors suggest that further studies be conducted on this topic to analyze other variables that may influence the actions of charismatic leadership. They also show that, if hospital managers want to promote initiate-oriented behaviors, they should adopt a charismatic leadership style. Therefore, charismatic leadership is an important competence for nurses in team management in hospitals.

In this sense, it is important to emphasize the dynamics of charismatic leadership as followers identify with the charismatic view because they consider it can help overcome existing problems ${ }^{(27)}$. Charismatic leadership transforms a follower's self-concepts and achieves its motivational results through at least four mechanisms: 
it changes the follower's perceptions of the work nature; it offers an attractive future vision; it promotes the development of a deep collective identity among followers; and it increases both individual and collective self-efficacy ${ }^{(28)}$.

The hospital environment was the study site of the three studies, in agreement with the results of an integrative review about nursing leadership, in which hospital institutions were also the site of most studies analyzed. The result is attributed to the researchers' apprehension regarding the challenges identified by some nurses to act as the leader in this scenario. Thus, leadership should be included in nursing courses, enabling professionals to lead in different processes in health ${ }^{(29)}$. In addition, the researchers also point out that nursing leadership helps overcome fragmented and inflexible behaviors seen in different health scenarios, as it favors new behaviors based on dialogue and evidence-based practices, with a consequent positive impact on the quality of care provided. It is also important to emphasize that the nurse leader can generate efficiency in the health and nursing team performance, promoting a critical, reflexive and participatory practice, and improving the satisfaction of patients, professionals and the institution ${ }^{(1,30)}$.

\section{Study limitations}

The words used in database search were in Portuguese, English and Spanish, which may not have included studies on charismatic leadership in languages other those above.

\section{Contributions to nursing, health or public policy}

Leadership is a critical competence for health professionals, especially for nursing professionals, because they can guide nursing actions for management and/or care. This integrative review synthesizes the knowledge produced about this theme, showing that, for involving the following characteristics of high self-confidence; mastery; conviction in the moral integrity of their beliefs, communication, possible use by nursing professionals in the various scenarios of action, leaders adopting charismatic leadership favor safer provision of better care to patients.

\section{CONCLUSION}

Charismatic leadership has attracted interest from professionals who work in health service management, especially nursing. Further studies should be conducted on the subject, since nursing leadership contributes to successful care provision.

In addition, the low number of studies found in the literature shows the great knowledge gap regarding charismatic leadership in nursing, which requires investments especially in hospitals, considering the instruments already tested for these specific environments.

It should be noted that the studies show charismatic leadership as an important competence for nursing professionals, generating positive influence on followers, especially in times of crisis and change.

\section{REFERENCES}

1. Amestoy SC, Backes VMS, Trindade L de L, Canever BP. The scientific production regarding leadership in the context of nursing. Rev Esc Enferm USP [Internet]. 2012 [cited 2017 Apr 12];46(1):227-33. Available from: http://dx.doi.org/10.1590/S0080-62342012000100030. English, Portuguese.

2. Dall'Agnol CM, Moura GMSS, Magalhaes AMM, Falk MLR, Riboldi CO, Oliveira AP. Motivations, contradictions and ambiguities in the leadership of nurses in management positions in a university hospital. Rev Lat Am Enfermagem [Internet]. 2013 [cited 2017 Sep 15];21(5):1172-8. Available from: http://dx.doi.org/10.1590/S0104-11692013000500022. English, Portuguese, Spanish.

3. Balsanelli AP, Cunha ICKO. Nursing leadership in intensive care units and its relationship to the work environment. Rev Lat Am Enfermagem [Internet]. 2015 [cited 2017 Apr 12];23(1):106-13. Available from: http://dx.doi.org/10.1590/0104-1169.0150.2531. English, Portuguese, Spanish.

4. Spagnol CA, L’Abbate S. Conflito organizacional: considerações teóricas para subsidiar o gerenciamento em enfermagem. Ciênc Cuid Saúde [Internet]. 2011 [cited 2017 Sep 15];9(4):822-7. Available from: http://periodicos.uem.br/ojs/index.phttp://dx.doi.org/10.4025/ cienccuidsaude.v9i4.7721 hp/CiencCuidSaude/article/view/7721/7203

5. Amestoy SC, Lopes RF, Santos BP, Dornelles C, Fuculo Junior PRB, Dos Santos EA. [Exercising leadership of nurses in the urgent and emergency service]. Rev Gest Sist Saúde [Internet]. 2015 [cited 2017 Sep 15];7(1):38-51. Available from: http://periodicos.unb.br/index. php/rgs/article/view/22065/15759 Portuguese.

6. Ministério da Educação (BR), Conselho Nacional de Educação. Resolução n. 3, de 07 de novembro de 2001. Diretrizes curriculares nacionais do curso de graduação em Enfermagem. [Internet]. Diário Oficial da União: República Federativa do Brasil; 2001 [cited 2017 Aug 18]. [about 2 screens]. Available from: http://www.cofen.gov.br/wp-content/uploads/2012/03/resolucao_CNE_CES_3_2001Diretrizes_Nacionais_ Curso_Graduacao_Enfermagem.pdf

7. Neves VR, Sanna MC. Concepts and practices of teaching and exercise of leadership in Nursing. Rev Bras Enferm [Internet]. 2016 [cited 2017 Sep 15];69(4):733-40. Available from: http://dx.doi.org/10.1590/0034-7167.2016690417i. English, Portuguese.

8. Costa SD, Silva PLN, Gonçalves RPF, Soares LM, Filho WA, Souto SGT. O exercício da liderança e seus desafios na prática do enfermeiro. J Manag Prim Heal Care [Internet]. 2017 [cited 2017 Sep 15];8(1):49-65. Available from: ttp://www.jmphc.com.br/jmphc/article/view/257

9. Amestoy SC, Pacheco LF, Guanilo MEE, Trindade LL, Silva CN. Exercício da liderança do enfermeiro em unidade de terapia intensiva. J Nurs Heal [Internet]. 2014 [cited 2017 Apr 12];4(2):143-54. Available from: https://periodicos.ufpel.edu.br/ojs2/index.php/enfermagem/article/ view/4271/3915

10. Wong CA, Spence LHK, Cummings GG. Authentic leadership and nurses' voice behaviour and perceptions of care quality. J Nurs Manag 
[Internet]. 2010 [cited 2017 Apr 12];18(8):889-900. Available from: http://onlinelibrary.wiley.com/doi/10.1111/j.1365-2834.2010.01113.x/epdf

11. Silva DS, Bernardes A, Gabriel CS, Rocha FLR, Caldana G. [The nurse's leadership within the context of emergency care services]. Rev Eletrônica Enferm [Internet]. 2014 [cited 2017 Feb 15];16(1):211-9. Available from: https://www.fen.ufg.br/fen_revista/v16/n1/pdf/ v16n1a24.pdf. Portuguese.

12. Farah BF, Dutra HS, Sanhudo NF, Costa LM. Percepção de enfermeiros supervisores sobre liderança na atenção primária. Rev Cuid [Internet]. 2017 [cited 2017 Sep 15];8(2):1638. Available from: https://www.revistacuidarte.org/index.php/cuidarte/article/view/398/800

13. Lanzoni GMM, Meirelles BHS. Leadership of the nurse: an integrative literature review. Rev Lat Am Enfermagem [Internet]. 2011 [cited 2017 Sep 15];19(3):651-8. Available from: http://dx.doi.org/10.1590/S0104-11692011000300026. English, Portuguese, Spanish.

14. Giltinane CL. Leadership styles and theories. Nurs Stand. 2013;27(41):35-9.

15. Chavaglia SRR, Dela Coleta MF, Dela Coleta JA, Mendes IAC, Trevizan MA. Adaptation and validation of the Charismatic Leadership Socialized Scale. Acta Paul Enferm [Internet]. 2013 [cited 2017 Sep 15];26(5):444-54. Available from: http://dx.doi.org/10.1590/S010321002013000500007. English, Portuguese.

16. de Vries RE, Bakker-Pieper A, Oostenveld W. Leadership = Communication? The Relations of Leaders' Communication Styles with Leadership Styles, Knowledge Sharing and Leadership Outcomes. J Bus Psychol [Internet]. 2010 [cited 2017 Sep 15];25(3):367-80. Available from: https://www.ncbi.nlm.nih.gov/pmc/articles/PMC2912722/pdf/10869_2009_Article_9140.pdf

17. Baesso MF, Lopes GSC, Morais DP, Rodrigues A. [The charismatic leadership in health organizations in the south of Santa Catarina. Navus] [Internet]. 2017 [cited 2017 Sep 15];7(3):19-33. Available from: http://navus.sc.senac.br/index.php/navus/article/view/527/pdf. Portuguese

18. Ehrhart MG. Self-Concept, Implicit Leadership Theories, and Follower Preferences for Leadership. Z Psychol [Internet]. 2012 [cited 2017 Sep 15];220(4):231-40. Available from: http://psycnet.apa.org/fulltext/2012-26405-005.pdf

19. Whittemore R. Combining evidence in nursing research: methods and implications. Nurs Res [Internet]. 2005 [cited 2017 Sep 15];54(1):56-62. Available from: $\mathrm{http}$ ://journals.Iww.com/nursingresearchonline/pages/articleviewer.aspx? year=2005\&issue $=01000 \&$ article=00008\&type=abstract

20. Ercole FF, Melo LS, Alcoforado CLGC. [Integrative review versus systematic review]. REME: Rev Min Enferm [Internet]. 2014;18(1):1-260. Available from: http://www.dx.doi.org/10.5935/1415-2762.20140001. Portuguese.

21. Mendes KDS, Silveira RCCP, Galvão CM. Integrative literature review: a research method to incorporate evidence in health care and nursing. Texto Contexto-Enferm [Internet]. 2008 [cited 2016 Dec 8];17(4):758-64. Available from: http://dx.doi.org/10.1590/S010407072008000400018. Portuguese.

22. Melnyk BM, Fineout-Overholt E. Evidence-based practice in nursing and healthcare: a guide to best practice. 3rd ed. Philadelphia: Wolters Kluwer Health/Lippincott; 2014. 625 p.

23. Işık O, Uğurluoğlu Ö, Akbolat M, Öner ZH, Pisapia JR. Charismatic leadership: Impulse factor for initiative-oriented health care personnel in the Turkish public hospitals. HealthMED [Internet]. 2012 [cited 2017 Sep 15];6(5):1523-35. Available from: http://pdf.healthmed.ba/ healthmed_6_5_web.pdf

24. Boerner S, Dütschke E. The impact of charismatic leadership on followers' initiative-oriented behavior. Health Care Manage Rev. 2008;33(4):332-40.

25. Ribeiro MAS, Vedovato TG, Lopes MHBM, Monteiro MI, Guirardello E de B. Validation studies in nursing: integrative review. Rev RENE. 2013;14(1):218-28.

26. Waldman DA, Ramirez GG, House RJ, Puranam P. Does Leadership Matter? CEO leadership attributes and profitability under conditions of perceived environmental uncertainty. Acad Manag J. 2001;44(1):134-43.

27. Jacobsen C, House RJ. Dynamics of charismatic leadership: a process theory, simulation model, and tests. Leadersh Q [Internet]. 2001 [cited 2017 Sep 15];12(1):75-112. Available from: https://doi.org/10.1016/S1048-9843(01)00065-0

28. Conger JA. Charismatic and transformational leadership in organizations. Leadersh Q [Internet]. 1999 [cited 2017 Sep 15];10(2):145-79. Available from: https://doi.org/10.1016/S1048-9843(99)00012-0

29. Mogollón SMR, González MA. Transactional and transformational leadership. Av Enferm [Internet]. 2010 [cited 2017 Sep 15];28(2):62-72. Available from: https://revistas.unal.edu.co/index.php/avenferm/article/view/21380/22432. Spanish.

30. Silva VLS, Camelo SHH. Nursing leadership competence: concepts, essential attributes and the role of the nurse leader. Rev Enferm UERJ [Internet]. 2014 [cited 2017 Sep 15];21(4):533-9. Available from: http://www.e-publicacoes.uerj.br/index.php/enfermagemuerj/article/ view/10031/18818. English, Portuguese. 